\title{
EFFECT OF ELECTRODES POSITION ON SEDIMENT MICROBIAL FUEL CELL OUTPUT VOLTAGES
}

\author{
Zahraa Salem Aswad, Ahmed Hassoon Ali, Nadia M. Al-Mhana \\ Environmental Engineering Department, College of Engineering, \\ Mustansiriyah University, Baghdad, Iraq
}

\begin{abstract}
Increasing global energy demand created a huge attention in utilizing numerous energy sources which are renewable and environmentally friendly. Sediment Microbial Fuel Cell (SMFC) is a very new technology and could be considered as renewable energy. Studying SMFC parameters help in opening doors for its amendment and innovate better methods in harvesting more voltages to generate biosensors or other applications. Two positions were appliyed to test the optimum one and study the relationship of water level and sun light and temperature by connecting them to get one answer. Vertical subsurface constructed wetland planted with Cyperus Alternifolius was implemented within two aquariums. The best output voltage was performed for embedded cathode position by reaching to $75 \mathrm{mV}$ whilst free cathode position hits value of $33 \mathrm{mV}$. Both types showed same pattern in changing of voltage except for the first five days when voltages decreased from (22.3-1.5 mV) and increased from (8-31.4 $\mathrm{mV}$ ) before starting to their peak values for embedded and free cathode positions, respectively.
\end{abstract}

Keywords: Sediment microbial fuel cell; Benthic microbial fuel cell; Graphite; Electrodes; Voltages; Bio-electricity generation; Wastewater.

Cite this Article: Zahraa Salem Aswad, Ahmed Hassoon Ali, Nadia M. Al-Mhana, Effect of Electrodes Position on Sediment Microbial Fuel Cell Output Voltages. International Journal of Civil Engineering and Technology, 11(4), 2020, pp. 152-160. https://iaeme.com/Home/issue/IJCIET?Volume=11\&Issue=4

\section{INTRODUCTION}

Nowadays, using of fossil fuel like oil and natural gas has been accelerated and in the coming future the world may face a lack in energy resources [1-2]. For minimizing $\mathrm{CO}_{2}$ emission, special attention has been paid to renewable energy resource [3]. Benthic or Sediment Microbial Fuel Cell (SMFC) is a novel technology and a innovated engineered treatment basin filled with granular and sediment media and planted with macrophytes which are crucial mainly for the treatment of wastewater by bacterial utilization to convert the metabolism of bacteria into bio-electricity [4]. SMFC can produce electricity and treat wastewater in parallel $[5,6]$. The existence of both organic matter and naturally redox gradients can be exploited to 
produce energy [7]. Conventional microbial fuel cell has two chambers which are separated by an ion exchange membrane [8] or salt bridge.

Two areas are required in SMFC, In anode chamber, which is under reduced redox conditions, anaerobic microorganism can grow and consume or oxidize substrate to produce electrons and protons and the other one is under higher redox potential where terminal electron acceptor is reduced. The electrons move from external circuit while protons transferred across a membrane [9]. Firstly, microbial fuel cell concept has been discussed by potter [10]. Small number of researchers focused on alternatives membrane. He and liu have removed the membrane from the cell [11]. However, Electrodes position plays a vital role in energy generating and electrons transition. It is changeable according to the type of microbial fuel cell, for example, in some researches; anode is put in the rhizosphere which will improve power generation of the system [12].

Redox potential decreases with depth generating a vertical redox gradient between the upper layer, which is in higher redox conditions, and the deeper layers where anaerobic environment predominates [13-14-15]. Main configuration for SMFC implementation in subsurface sediment microbial fuel cell relies on setting cathode at the surface while anode remains buried in the deeper zone of bed. The evapotranspiration which is caused by plants and weather is marked daily on water level within the treatment bed and therefore it perceptibly has an influence on wetlands' redox conditions [16].

Notable fluctuations of water table caused by plants evapotranspiration may vary MFC performance on daily and seasonal terms by changing the availability of oxygen at the cathode. Consistent with this, cathode has been considered to be one of the major sources of limitation in CWMFCs due to the slow kinetics of oxygen reduction and the scarcity of oxygen in CW environment [17].

Therefore, the purpose of this study was to determine the influence of water level indirectly on the performance of SMFC by using plant with real domestic wastewater.

The implementation of MFCs in CWs and studying the effect of electrodes position and in particular on subsurface constructed wetlands is in its first stage and current scientific information accessible on the topic is poor. So far, some studies have been developed in pilot scale systems [17-18], where most of them were basically relied on laboratory scale experimental designs [19-20-21] and used synthetic or simulated wastewater instead of real wastewater.

\section{MATERIALS AND METHODS}

\subsection{Constructed Wetlands' Fabrication}

Two $40 \mathrm{~cm}$ diameter and $53 \mathrm{~cm}$ height cylindrical aquariums were used. Three sizes of gravels were constructed and arranged within three layers, from the bottom to top, depths were 10,10 , and $6 \mathrm{~cm}$ and gravel sizes were $(80-40 \mathrm{~mm}),(30-50 \mathrm{~mm})$, and $(10-6 \mathrm{~mm})$, respectively. The last top layer of $5 \mathrm{~cm}$ was sieved sand with a diameter of less than $2 \mathrm{~mm}$. for wastewater sampling; $2 \mathrm{~cm}$ diameter nozzle was established above a distance of $1 \mathrm{~cm}$ from the bottom of aquarium. 

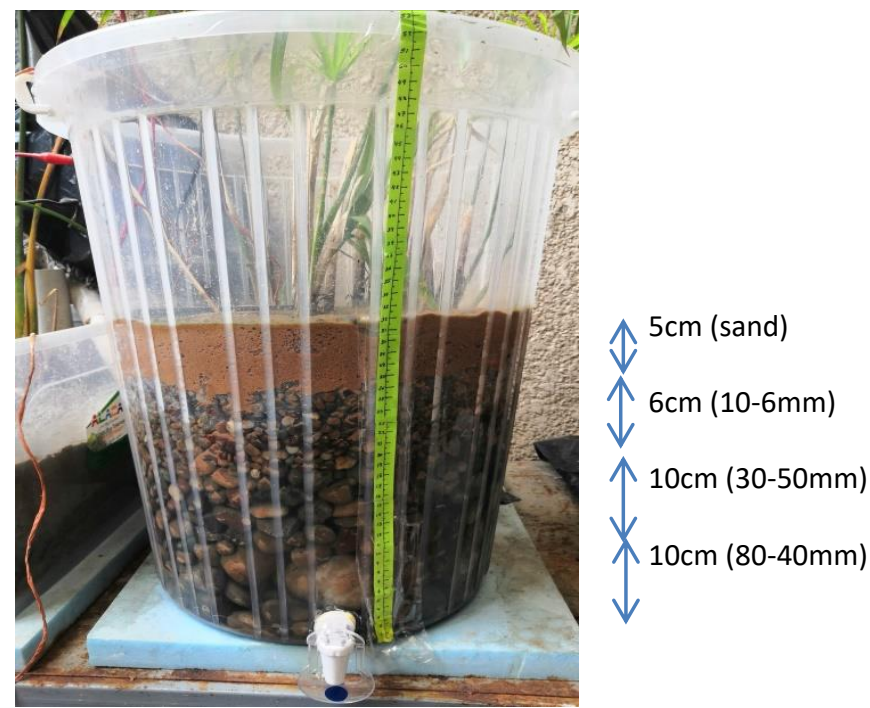

Figure 1 Fabrication of constructed wetland (Aquarium)

\subsection{Preparations of Plants}

Cyperus Alternifolius or umbrella papyrus is the plant of our study. Each aquarium was planted with three shoots. Dead leaves and stems have been harvested to keep the plant healthy and active for the formation of roots.

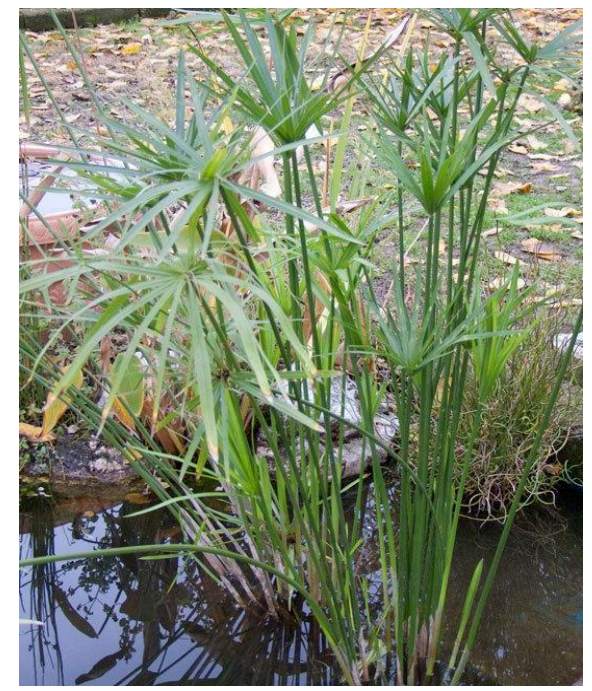

Figure 2 Cyperus Alternifolius

\subsection{Electrodes Preparation}

Electrodes are crucial for completing electrical circuit, two electrodes; made of graphite with surface area of $110 \mathrm{~cm} 2$ were used. They have been pretreated and soaked in distilled water for 24 hours to clean any suspended particles on them. Pretreated electrodes can provide best microbes adhesion and propagation, and enhancing the performance of reactor. After that, they have been connected with insulated copper wire. The other end of electrode is connected with alligator clip. Solder has been used to avoid any loses or corrosion in copper wire Alligator clip helps to hold the external resistor and measuring the current and voltage of fuel cell from the multi-meter. Hence, the other electrodes in this study were prepared as the same of above manner. 


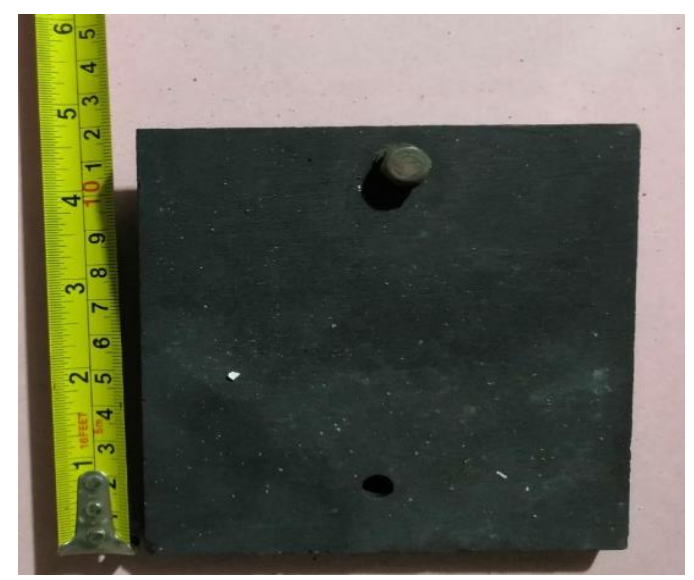

Figure 3 The size and shape of electrodes used

\subsection{Wastewater Preparation}

Wastewater samples were collected from Al-Rustamiyah wastewater treatment plant influent. The old project of Al-Rustamiyah wastewater treatment plant is located in Baghdad $\left(33^{\circ} 16^{\prime}\right.$ $\left.30.8^{\prime \prime} \mathrm{N}, 44^{\circ} 31^{\prime} 57.4^{\prime \prime} \mathrm{E}\right) .6$ liters of wastewater was needed for each aquarium to be filled with.

\subsection{SMFC's Configuration and Monitoring}

Two SMFC were implemented within the vertical subsurface constructed wetlands VSS CW. They were operated at closed circuit by connecting both electrodes with one external resistance by copper wires. SMFCs were monitored during two consecutive periods of 19 days each in which two different anode and cathode positions were tested. for the first aquarium, cathode was placed above the sediment (sand layer) or on soil-air interference. While the second aquarium, cathode was placed inside $(6-10 \mathrm{~mm})$ gravel layer. Anode electrode is stayed embedded for the first and second aquariums, in sand- $(6-10 \mathrm{~mm})$ gravel layer interference and inside the sand layer, respectively. SMFCs were connected to a Multimeter which collected a value of voltage and current across the external resistance every 12 hrs.

\section{RESULTS AND DISCUSSION}

\subsection{Effect of Temperature on Voltages}

Temperature is described to affect VSS CW microbial processes [22]. Sediment microbial fuel cell function in a microbial basis and as in the conventional MFC, temperature may also affect their performance [23]. Relatively, meteorological data of both periods (day and night) was recorded to ensure that they are comparable in a term of temperature. Results showed very cold temperatures at the whole periods $(9 \pm 9)$ thus both aquariums were tested during the same month (December). As shown in figure (4) and figure (5) fluctuation in temperature from $\left(2-19^{\circ} \mathrm{C}\right)$ is noticeable as voltages were recorded during day and night. Temperature has a slight effect on output voltages because it was increasing and decreasing in a limited range but with highest temperatures, for example, $25^{\circ} \mathrm{C}$ or more; metabolism activity would taking place inside the sediment. Thus producing more electrons and efficient voltage 


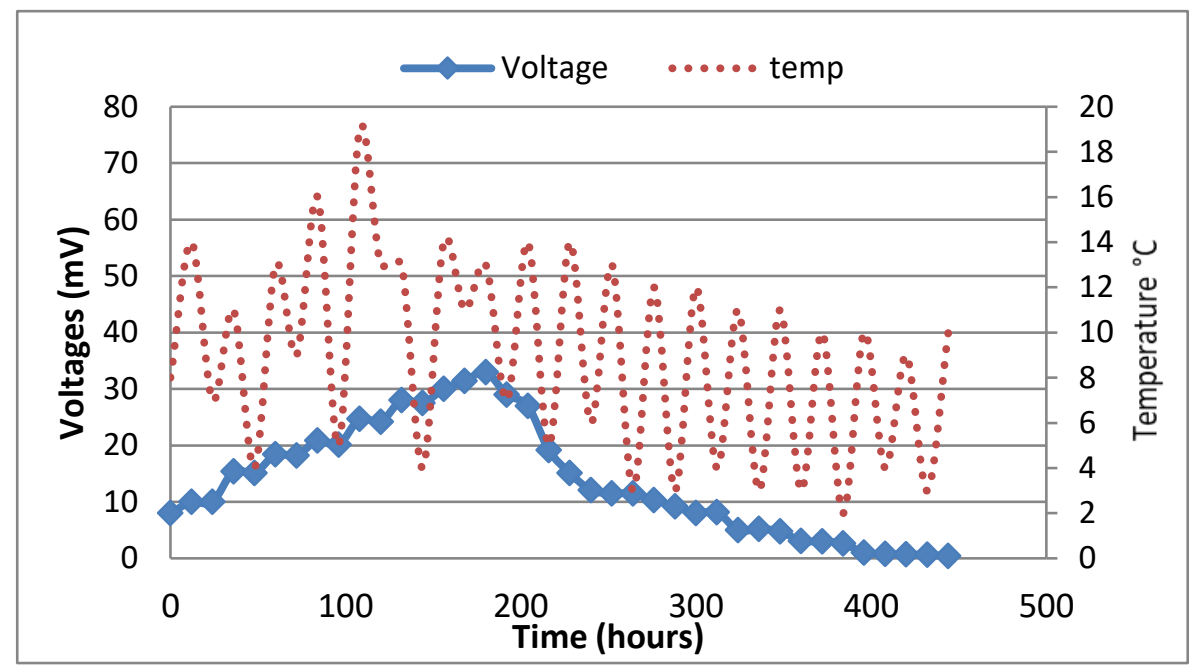

Figure 4 Representative cell voltage pattern for free cathode position under the effect of temperature for 444 hours

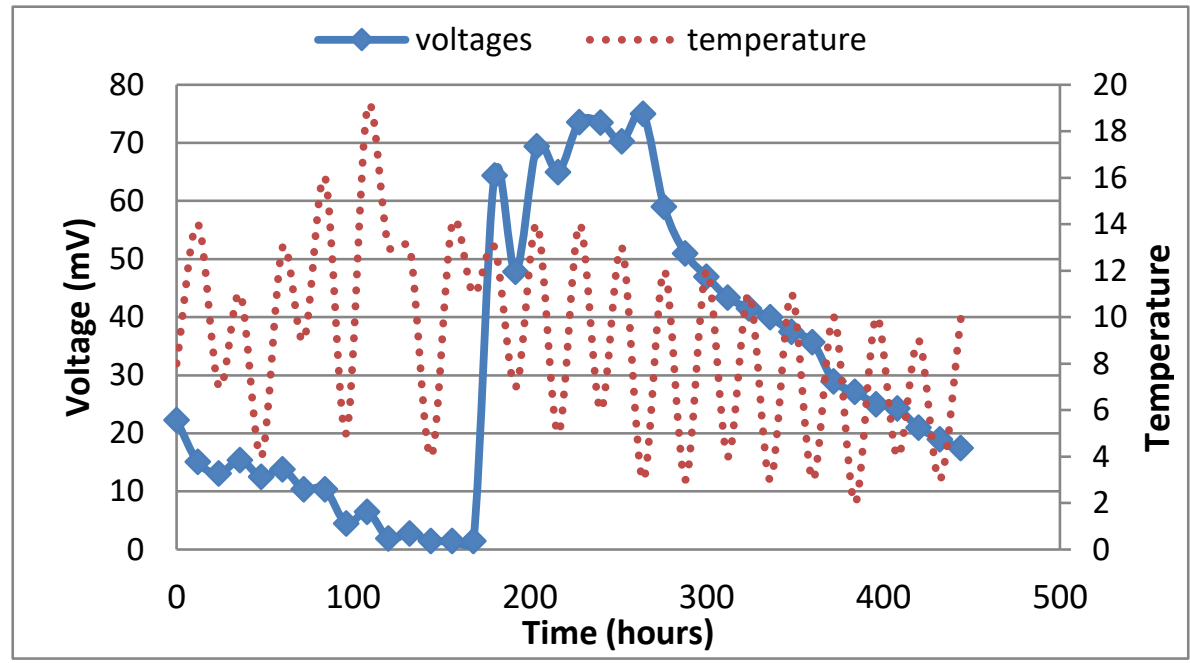

Figure 5 Representative cell voltage pattern for embedded cathode position under the effect of temperature for 444 hours

\subsection{Voltage Pattern during Day and Night}

\subsubsection{For free Cathode Position}

Cell voltage was assessed by comparing SMFC performance under different periods. One thing must be pointed out that cell voltage along the day during cold or intensive months especially at the first days of running the experiments; SMFC was close to zero but increased with time. For the first five days, voltage was low and increased dramatically to reach to (31.4 and $33 \mathrm{mV}$ ). By generating current and voltages, losses started to disappear and ohmic losses rise. After several hours, voltages decrease from $(29$ and $27 \mathrm{mV}$ ) to reach approximately closer to zero. The cause of this phenomenon is that region of concentration over potential would appear and losses are due to impede the delivery of hydrogen and oxygen gases to cathode region.

All results showed that maximum cell voltage values were recorded for MFC working under sufficient water level (WL) conditions on which cathode is touched by WL. 
In a nutshell, output voltage has a similar pattern in both periods but it increased during sun light especially in winter with low evaporation problems affecting the overlaying cathode [16].

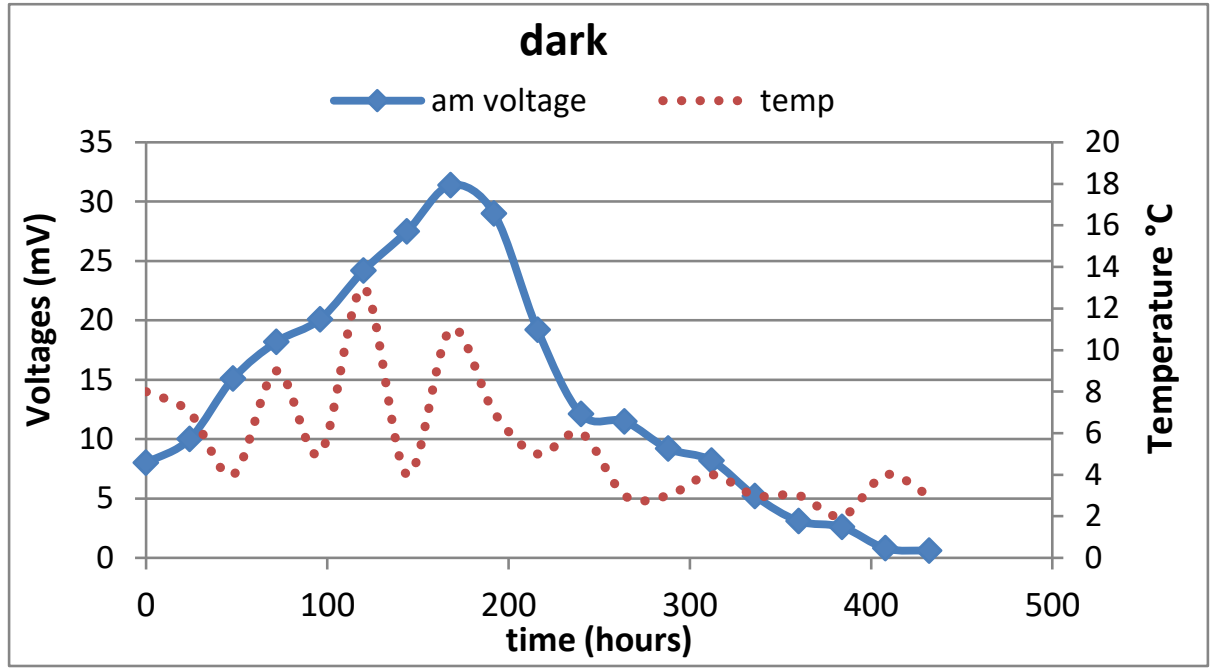

Figure 6 Representative cell voltage pattern for free cathode position under the effect of temperature for 432 hours (Dark period)

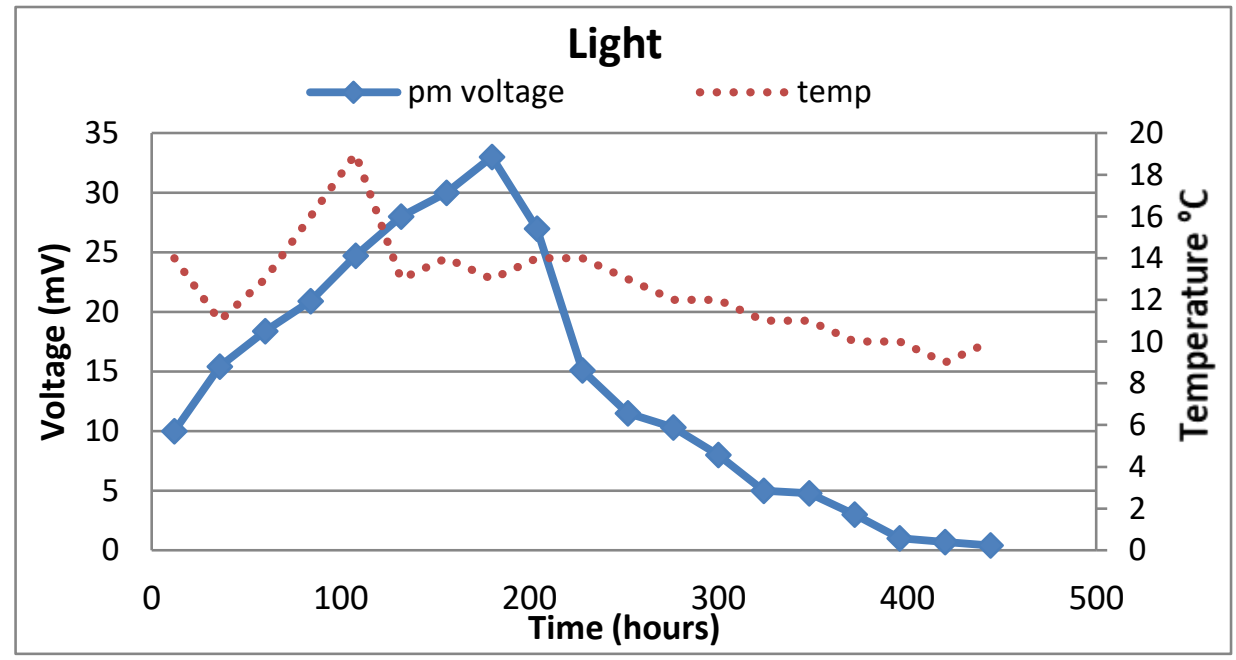

Figure 7 Representative cell voltage pattern for free cathode position under the effect of temperature for 444 hours (light period)

\subsubsection{For Embedded Cathode Position}

Sediment is a very common inoculating source of various biological treatment technologies; richness of microorganism in sediment suggests its potential as SMFCs anode substrate [24]. Hence in this type of SMFC both anode and cathode were embedded in deep layers with maintaining the distance between two electrodes $5 \mathrm{~cm}$.

Anode was located inside sediment layer near rhizosphere to get more benefit of microorganisms of root and phytosynthesis of plant. So that, the author of this study supposed that anode position plays a crucial role in this current aquarium. As mentioned before, day and night variation does not have a significant impact on voltages; despite of the maximum voltage was recorded during night period. More electrons were maintained when cathode was embedded inside layers on which WL variation does not affect SMFC efficiency. On a contrary to the previous position type, at the beginning of experiment, voltage was ( 22 and 15 
$\mathrm{mV}$ ) and decreased until day 7 and 8. After that, it started to increase and reached to maximum vales of voltages $(75$ and $73.6 \mathrm{mV})$ during night and day periods, respectively. However, more output voltages are due to more redox processes happened inside the sediment and hence we conclude that water level inside the bed and plant suction or evaporation by plants for water plays an important role in output voltage especially when voltages decreased as a reason for mentioned reasons above.

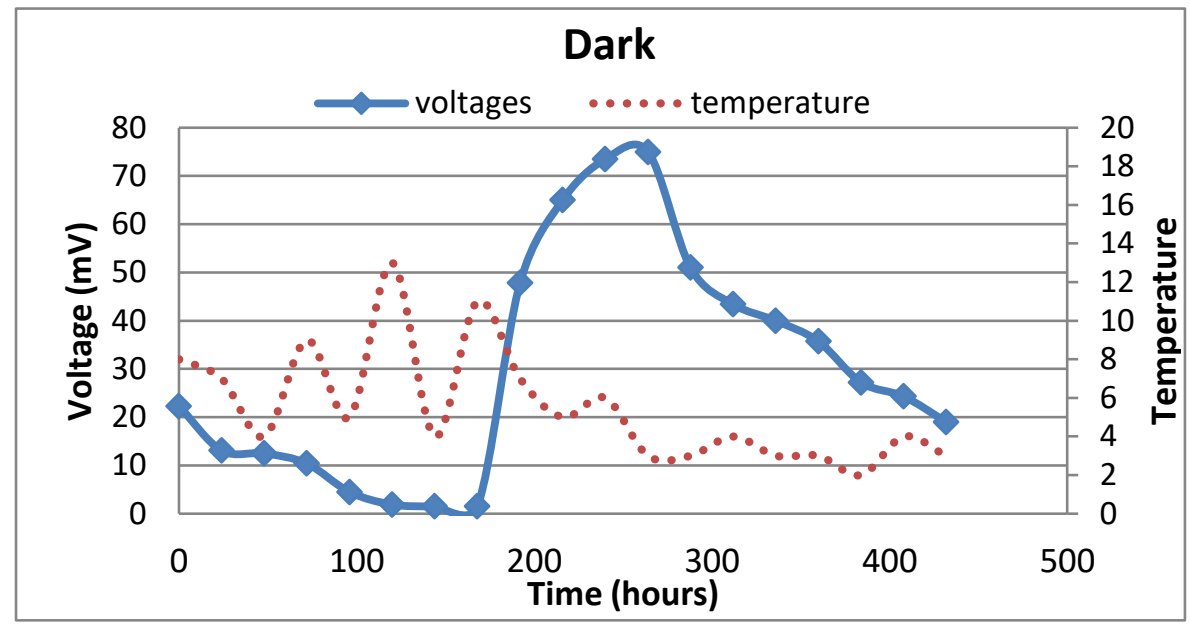

Figure 8 Representative cell voltage pattern for embedded cathode position under the effect of temperature for 432 hours (Dark period)

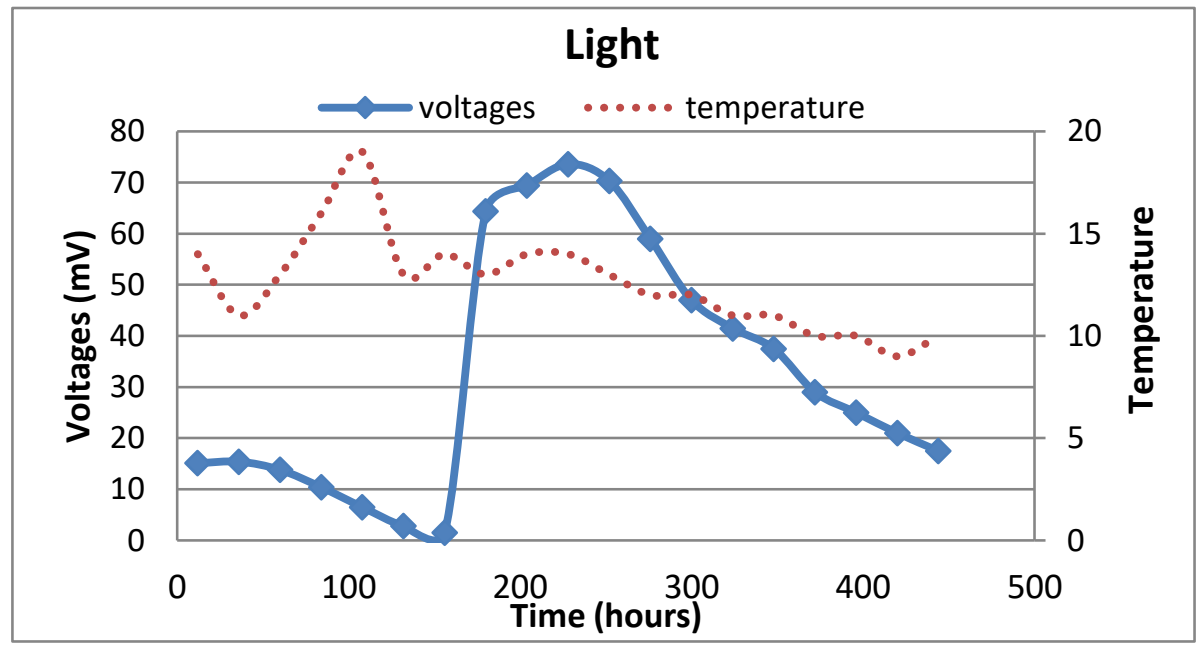

Figure 9 Representative cell voltage pattern for embedded cathode position under the effect of temperature for 444 hours (light period)

\section{CONCLUSIONS AND RECOMMENDATIONS}

- Plant-SMFC combined systems, if more mechanisms between plant and SMFC are revealed, methods to optimize and strengthen the plant-SMFC combined system will be clearer.

- Water level variation in constructed wetlands which is particularly caused by evapotranspiration of plant (suction of plant for water) has a great effect on sediment microbial fuel cell performance. 
- Cathode shall remain between fuel cell layers and close to the anode to optimize performance of fuel cell.

- Water level variation influences cathode performance by increasing the overall internal resistance of the system.

- Hydrogen and oxygen are important factors in enhancing cathode chamber

- Sediment fed with waste water is relatively anaerobic and is considered to be a good environment for anode placement rather than placing it between gravels layers as happened in the first experiment.

- Temperature has an impact along the year (different range of temperature) but it is barely considered in varying the output voltage for sequences days.

- Photosynthesis could verify the reason behind a good output voltage when anode is placed near the rhizosphere.

\section{ACKNOWLEDGMENT}

The author of the present work would like to thank Mustansiriyah University (www.uomustansiriyah.edu.iq) for its support to carry out this research.

\section{REFERENCES}

[1] Logan, B.E. et al., 2006. Microbial fuel cells: methodology and technology. Environmental Science and Technol. 40(17): 5181-5192. AL-Degs .Y, El-Sheikh .A .H, Al-Gouti, .M .A. , Sunjuk .M .S, "Determination of commercial colorants in different water bodies using partial least squares regression (PLS)", Jord. J. Chem., 3, 2008, pp. 321-336.

[2] Rahimnejad, M. et al., 2009. Effective Parameters on Performance of Microbial Fuel Cell. IEEE.

[3] Du, Z., H. Li and T. Gu, 2007. A state of the art review on microbial fuel cells: a promising technology for wastewater treatment and bioenergy. Biotechnology Advances, 25(5): 464-482.

[4] Song, T. et al., 2009. Electricity generation from terephthalic acid using a microbial fuel cell. J. Chemical Technology and Biotechnol., 84(3): 356-360.

[5] Kim, H.J. et al., 2002. A mediator-less microbial fuel cell using a metal reducing bacterium, Shewanella putrefaciens. Enzyme and Microbial Technol., 30(2): 145-152.

[6] Gil, G.C., et al., 2003. Operational parameters affecting the performannce of a mediatorless microbial fuel cell. Biosensors and Bioelectronics, 18(4): 327-334.

[7] Corbella, C., Garfí, M., Puigagut, J., 2014. Vertical redox profiles in treatment wetlands as function of hydraulic regime and macrophytes presence: surveying the optimal scenario for microbial fuel cell implementation. Sci. Total Environ. 470-471, 754-758.

[8] Ren, Z., T.E. Ward and J.M. Regan, 2007. Electricity production from cellulose in a microbial fuel cell using a defined binary culture. Environmental science and Technol., 41(13): 4781-4786.

[9] Ghangrekar, M. and V. Shinde, 2007. Performance of membrane-less microbial fuel cell treating wastewater and effect of electrode distance and area on electricity production. Bioresource Technol., 98(15): 2879-2885.

[10] He, Z. and L.T. Angenent, 2006. Application of bacterial biocathodes in microbial fuel cells. . Electroanalysis, 18(1920): 2009-2015.

[11] Logan, B.E., et al., 2006. Microbial fuel cells: methodology and technology. Environmental Science and Technol., 40(17): 5181-5192. 
[12] De Schamphelaire L, Van den Bossche L, Dang H S, Höfte M, Boon N, Rabaey K, Verstraete W. Microbial fuel cells generating electricity from rhizodeposits of rice plants. Environmental Science \& Technology, 2008, 42(8): 3053-3058

[13] Dušek, J., Picek, T.,Č́žková,H.,2008.Redox potential dynamics in a horizontal subsurface flowconstructedwetlandforwastewatertreatment:diel,seasonalandspatialfluctuations. Ecol. Eng. 34 (3), 223-232.

[14] García, J., Ojeda, E., Sales, E., Chico, F., Píriz, T., Aguirre, P., Mujeriego, R.,2003. Spatial variations of temperature, redox potential, and contaminants in horizontal flow reed beds. Ecol. Eng. 21 (2-3), 129-142.

[15] Pedescoll, A., Sidrach-Cardona, R., Sánchez, J.C., Bécares, E., 2013. Evapotranspiration affecting redox conditions in horizontal constructed wetlands under Mediterranean climate: influence of plant species. Ecol. Eng. 58, 335-343.

[16] Mann,C.J.,Wetzel,R.G.,1999.PhotosynthesisandstomatalconductanceofJuncuseffusus in a temperate wetland ecosystem. Aquat. Bot. 63 (2), 127-144.

[17] Villaseñor, J., Capilla, P., Rodrigo, M.A., Cañizares, P., Fernández, F.J., 2013. Operation of a horizontal subsurface flow constructed wetland-microbial fuel cell treating wastewater under different organic loading rates. Water Res. 47 (17), 6731-6738.

[18] Doherty, L., Zhao, Y., Zhao, X., Hu, Y., Ao, X., Xu, L., Liu, R., 2015. A review of a recently emerged technology: Constructed wetland - microbial fuel cells. Water Res. 85 (15), 38-45.

[19] Yadav,A.K.,Dash,P.,Mohanty,A.,Abbassi,R.,Mishra,B.K.,2012.Performanceassessment of innovative constructed wetland-microbial fuel cell for electricity production and dye removal. Ecol. Eng. 47, 126-131.

[20] Zhao,Y., Collum, S., Phelan, M., Goodbody, T., Doherty, L., Hu, Y., 2013. Preliminary investigation of constructed wetland in corporating microbial fuel cell: Batch and continuous flow trials. Chem. Eng. J. 229, 364-370.

[21] Fang, Z., Song, H.-L., Cang, N., Li, X.-N., 2013. Performance of microbial fuel cell coupled constructed wetland system for decolorization of azo dye and bioelectricity generation. Bioresour. Technol. 144, 165-171.

[22] García, J., Rousseau, D.P.L., Morató, J., Lesage, E., Matamoros, V., Bayona, J.M., 2010. Contaminant removal processes in sub surface-flow constructed wetlands: a review. Water Res. 40 (7), 561-661.

[23] Jadhav, G.S., Ghangrekar, M.M., 2009. Performance of microbial fuel cell subjected to variation in $\mathrm{pH}$, temperature, external load and substrate concentration. Bioresour. Technol. 100 (2), 717-723.

[24] Wolińska A, Stępniewska Z, Bielecka A, Ciepielski J. Bioelectricity production from soil using microbial fuel cells. Applied Biochemistry and Biotechnology, 2014, 173(8): 22872296 